\title{
RT-nested PCR detection of Mourilyan virus in Australian Penaeus monodon and its tissue distribution in healthy and moribund prawns
}

\author{
Jeff A. Cowley ${ }^{1, *}$, Russell J. McCulloch ${ }^{1}$, Rajendran KV ${ }^{1}$, Lee C. Cadogan ${ }^{1}$, \\ Kirsten M. Spann ${ }^{1,2}$, Peter J. Walker ${ }^{1}$
}

${ }^{1}$ CSIRO Livestock Industries, Queensland Bioscience Precinct, 306 Carmody Road, St. Lucia 4067, Australia

${ }^{2}$ Present address: Laboratory of Infectious Diseases, National Institute of Allergy and Infectious Diseases, Bethesda, Maryland 20892-0720, USA

\begin{abstract}
Mourilyan virus (MoV) is a newly identified virus of Penaeus monodon prawns that is genetically related to the Uukuniemi virus and other phleboviruses of the Bunyaviridae. This paper describes an RT-nested PCR test that can reliably detect between 2 and 6 copies of a synthetic MoV RNA. Total RNA isolated from the lymphoid organ, gills and haemocytes of $P$. monodon with moderate infections gave comparable amplicon yields in the RT-PCR step of the test. However, in prawns with extremely low-level infections, haemocytes and gill tissue proved slightly more reliable in detecting MoV RNA following nested PCR. The distribution of MoV in tissues of healthy and moribund $P$. monodon was examined by in situ hybridisation (ISH) using a digoxigenin-labelled DNA probe to a $\sim 0.8 \mathrm{~kb}$ M RNA segment cDNA insert in clone $\mathrm{pMoV} 4.1$. The DNA probe targeted a region in the MoV M RNA segment containing a coding sequence with homology to the C-terminus of the G2 glycoprotein of phleboviruses. In healthy prawns harbouring an unapparent MoV infection, ISH signal primarily occurred in the lymphoid organ, where it was more prominent in hypertrophied cells of 'spheroids' than within cells of normal tubules. ISH signal was also sometimes detected in cells of cuticular epithelium, segmental nerve ganglion and the antennal and tegmental glands. MoV was distributed widely throughout these and other cephalothoracic tissues of mesodermal and ectodermal origin in moribund P. monodon following experimental infection or collected from farm pond edges during disease episodes. Transmission electron microscopy of gill of moribund, captive-reared P. monodon identified spherical ( 85 nm diameter) to ovoid MoV particles $(\sim 85 \times 100 \mathrm{~nm})$ in and around highly necrotic cells in which the nucleus and other organelles had disintegrated. MoV virions co-existed with rod-shaped virions of gill-associated virus and were often seen clustered within cytoplasmic vacuoles or associated with the outer rim of concentric ring-shaped structures comprised of endoplasmic membranes likely to represent degenerated Golgi.
\end{abstract}

KEY WORDS: Mourilyan virus · Uukuniemi virus · Phlebovirus · Bunyavirus · Penaeus monodon • Penaeid shrimp · Prawn · In situ hybridisation $\cdot$ PCR

\section{INTRODUCTION}

The giant tiger prawn Penaeus monodon is cultivated widely throughout south-east Asia, India and Australia. Due to its commercial importance to these regions, viral diseases of this prawn species have been the focus of intense investigation. Viruses identified in $P$. monodon from eastern Australia include monodon baculovirus
(MBV) (Doubrovsky et al. 1988, Belcher \& Young 1998, Vickers et al. 2000), a lymphoidal parvo-like virus (LPV) (Owens et al. 1991), gill-associated virus (GAV) (Spann et al. 1995, 1997, Cowley et al. 1999, 2000a, Smith 2000, Callinan et al. 2003) and spawner-isolated mortality virus (SMV) (Fraser \& Owens 1996, Owens et al. 1998, 2003). A virus with spherical enveloped particles ( $74 \mathrm{~nm}$ average diameter) has also been detected in 
eye tissues of moribund farmed prawns (Smith 2000) and although they were slightly larger, some morphological similarity was noted to a reo-like virus detected in Malaysian P. monodon (Nash et al. 1988). Moreover, a small virus causing infectious hypodermal and haematopoietic necrosis virus (IHHNV)-like pathology (Owens et al. 1992) and a haemocytic rod-shaped virus (Owens 1993) were among 4 virion types found in diseased experimental hybrids of $P$. monodon and $P$. esculentus generated at a research facility in north Queensland in the early 1990s. More recently, a virus genetically related to bunyaviruses named Mourilyan virus (MoV) (Cowley et al. 2005), and IHHNV (Krabsetsve et al. 2004) have been detected in P. monodon from eastern Australia.

Sensitive PCR tests targeting gene sequences of viruses such as MBV (Belcher \& Young 1998), GAV (Cowley et al. 2000a, Walker et al. 2001) and SMV (Owens et al. 2003) have been used to assess their prevalence and geographic distribution in Australian prawns. In situ hybridisation (ISH) using gene probes to SMV (Owens et al. 1998), YHV (Tang \& Lightner 1999, Tang et al. 2002) and GAV (Spann et al. 2003) has associated these viruses with histopathology and helped determine their tissue distribution in chronically and acutely infected prawns. In this paper, we have used a sensitive RT-nested PCR test targeted to a region of the MoV M RNA segment with significant homology to the cognate RNA segment of Uukuniemi virus (Cowley et al. 2005) to assess its prevalence in Penaeus monodon from eastern Australia. ISH with a DNA probe also targeted to this region of the M RNA was used to assess the tissue distribution of MoV in healthy as well as moribund $P$. monodon with either natural or experimentally induced acute infections. Within highly necrotic cells in the gill epithelia of moribund, captive-reared P. monodon, transmission electron microscopy (TEM) identified bunyavirus-like spherical to ovoid MoV particles clustered within cytoplasmic vacuoles or associated with membranous concentric ring structures.

\section{MATERIALS AND METHODS}

Prawns and viral inoculum. Penaeus monodon broodstock were obtained from commercial hatcheries, the Australian Institute of Marine Science (AIMS), Cape Ferguson, and CSIRO Marine Research, Cleveland. Healthy and moribund juvenile prawns were collected from farms in southeast Queensland. All prawns originated from wild stock from coastal waters in the Innisfail $\left(17^{\circ} 31^{\prime} \mathrm{S}, 146^{\circ} 01^{\prime} \mathrm{E}\right)$ to Cairns $\left(16^{\circ} 55^{\prime} \mathrm{S}, 145^{\circ} 46^{\prime} \mathrm{E}\right)$ region of north Queensland. Other broodstock originated from Weipa $\left(12^{\circ} 38^{\prime} \mathrm{S}\right.$, $\left.141^{\circ} 53^{\prime} \mathrm{E}\right)$ in the Gulf of Carpentaria, northwest Queensland. All prawns examined were sampled between December 1996 and April 2004. Body weight, sex and general appearance of prawns were recorded at the time of sampling. The locality from which prawns were sourced, the date they were sampled and whether they were sampled pre- and post-spawning are indicated in the text. The source of the moribund, farmed P. monodon used to prepare the pathogenic inoculum containing $\mathrm{MoV}$ and GAV, and its method of production, have been described previously (Spann et al. 1997). Prawns were infected experimentally by intramuscular injection of the inoculum at a dose of $5 \mu \mathrm{l}$ $\mathrm{g}^{-1}$ body weight as described previously (Spann et al. 1997) and moribund prawns were sampled $5 \mathrm{~d}$ after injection when significant mortalities were occurring.

RNA isolation. Following euthanasia of prawns, tissues were collected using surgical instruments that were heat-sterilised after each operation to avoid cross-contamination. Dissected tissue pieces were snap-frozen on dry ice immediately after collection and stored at $-80^{\circ} \mathrm{C}$. Total cellular RNA was generally extracted from 10-75 mg prawn tissue (lymphoid organ, gill or haemocytes). Tissue was disrupted in $750 \mu \mathrm{l} \mathrm{TRIzol}{ }^{\mathrm{TM}}$ reagent (Invitrogen) by pulverization for $30 \mathrm{~s}$ in tubes containing 3 sterilized glass beads using a Savant FastPrep FP120 beater. RNA was isolated as described in the $\mathrm{TRIzol}^{\mathrm{TM}}$ protocol, resuspended in $25 \mu \mathrm{l}$ RNase-free water, quantified by spectrophotometry $\left(\mathrm{A}_{260 \mathrm{~nm}}\right)$ and stored at $-80^{\circ} \mathrm{C}$. To prevent contamination with PCR products, aerosol-resistant barrier pipette tips were used and all RNA isolation processes were conducted in a fume cupboard and biological safety cabinet in laboratories separate from those used for PCR set up and gel analysis.

PCR primers. PCR primers MoV24F (5'-GGG ATG GTG TTG CCA TAC AAA GG-3') and MoV25R (5'GTC ATT AGC TGG TCT TAG TTT TCA C-3') were designed to amplify a 610 bp region of the 776 nucleotide (nt) MoV M RNA segment in cDNA clone pMoV4.1 (GenBank Acc: AY927991). This clone was obtained by serendipity from a cDNA library prepared to a $22 \mathrm{kbp}$ dsRNA isolated from lymphoid organ tissue of Penaeus monodon dually infected with GAV and MoV (Cowley et al. 2000b, 2005). Nested primers MoV148F (5'-ACA GTT TGT CAA GCT CAC AGG ATG-3') and MoV149R (5'-AGA AGC GCC ATT CTG ATG AAC ATC-3') were designed to amplify a $322 \mathrm{bp}$ internal region of the primary PCR amplicon.

MoV synthetic RNA. High quality plasmid DNA was prepared for MoV cDNA clone pMoV4.1 using the CONCERT ${ }^{\mathrm{TM}}$ Rapid Plasmid Miniprep System (Invitrogen). pMoV4.1 DNA was linearized at the Eco RI site in the UNI-primer (Cowley et al. 2000b) at the 3 '-end of the cDNA insert (this site was mutated in the $5^{\prime}$-UNI- 
primer) and purified using a QIAquick $^{\circledR}$ Purification Column (QIAGEN). A (+) sense RNA transcript was synthesised from $1.5 \mu \mathrm{g}$ DNA using T7 RNA polymerase and the Riboprobe ${ }^{\circledR}$ in vitro Transcription System (Promega). After incubation at $37^{\circ} \mathrm{C}$ for $2 \mathrm{~h}$, DNA was removed by incubation with $2 \mathrm{U}$ RQ1-DNase (Promega) at $37^{\circ} \mathrm{C}$ for $20 \mathrm{~min}$. RNA was extracted with an equal volume of TE-saturated phenol:chloroform: isoamyl alcohol (25:24:1 [pH 4.5]) followed by chloroform:isoamyl alcohol $(24: 1)$ and precipitated at $-70^{\circ} \mathrm{C}$ for 30 min following the addition of $2.5 \mathrm{M}$ ammonium acetate and $2.5 \mathrm{vol} 100 \%$ ethanol. The RNA pellet was collected by micro-centrifugation for $15 \mathrm{~min}$, washed twice using $75 \%$ ethanol, vacuum dried for $10 \mathrm{~min}$, resuspended in $50 \mu \mathrm{l}$ RNase-free water and stored at $-80^{\circ} \mathrm{C}$.

Three independent aliquots of the 849 nt synthetic MoV RNA were quantified by spectrophotometry $\left(\mathrm{A}_{260 \mathrm{~nm}}\right)$ and the number of RNA molecules was calculated from mass $\left(289613.8 \mathrm{~g} \mathrm{~mol}^{-1}\right)$ and concentration $\left(1 \mathrm{~A}_{260 \mathrm{~nm}}=34.9 \mu \mathrm{g} \mathrm{ml}^{-1}\right)$ data determined using the Biopolymer Calculator Version 4.1.1 software (see http://paris.chem.yale.edu/extinct.html). A stock containing $2 \times 10^{10}$ RNA molecules $\mu^{-1}$ was prepared in

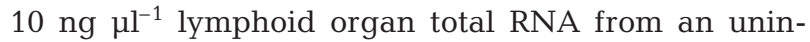
fected Penaeus merguiensis and 10-fold dilution series were prepared using the same $P$. merguiensis RNA diluent. Replicate RNA dilutions containing 600, 200, $60,20,6,2,0.6,0.2$ and 0.02 synthetic RNA molecules $\mathrm{ul}^{-1}$ were prepared below the dilution containing $2 \times$ $10^{3}$ molecules $\mu^{-1}$ to better estimate the sensitivity limits of the MoV RT-PCR and nested PCR.

RT-nested PCR and sequence analysis. cDNA was synthesised from prawn total RNA $(1.0 \mu \mathrm{g}$ RNA per $10 \mu \mathrm{l}$ reaction) using $50 \mathrm{pmol}$ random hexamer primers (Promega or Fisher Biotech), $1 \mathrm{mM}$ each dNTP and either 100 U Superscript II or III reverse transcriptase (Invitrogen) exactly as described in the manufacturer's protocols. To determine the sensitivity of the RT-nested PCR, cDNA was prepared using 10 -fold serial dilutions of in vitro-transcribed synthetic MoV RNA diluted in a

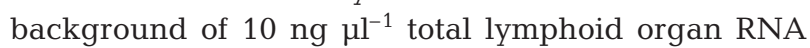
from an uninfected Penaeus merguiensis. In the primary PCR, a $1 \mu$ portion of the cDNA reaction (equivalent to $100 \mathrm{ng}$ total RNA) was amplified in a $25 \mu \mathrm{l}$ reaction containing Promega Taq buffer $(10 \mathrm{mM}$ Tris$\mathrm{HCl} \mathrm{pH} \mathrm{9.0,50} \mathrm{mM} \mathrm{KCl,} \mathrm{0.1 \%} \mathrm{Triton} \mathrm{X-100),} 2.5 \mathrm{mM}$ $\mathrm{MgCl}_{2}, 12.5 \mathrm{pmol}$ each primer MoV24F and MoV25R, $200 \mu \mathrm{M}$ each dNTP and 1.25 U Taq DNA polymerase (Promega). Alternatively, PCR amplifications of comparable sensitivity were performed using $1 \times \mathrm{Taq}$ buffer $\left(6.7 \mathrm{mM}\right.$ Tris- $\mathrm{HCl} \mathrm{pH}$ 8.8, $16.6 \mathrm{mM}\left[\mathrm{NH}_{4}\right]_{2} \mathrm{SO}_{4}$, $0.45 \%$ Triton X-100, $0.2 \mathrm{mg} \mathrm{m}^{-1}$ gelatin) and $1.38 \mathrm{U}$ Taq DNA polymerase (Fisher Biotec). DNA was amplified in a BIO-RAD iCycler using the conditions of $95^{\circ} \mathrm{C}$ for $2 \mathrm{~min}, 35$ cycles of $95^{\circ} \mathrm{C}$ for $30 \mathrm{~s}, 60^{\circ} \mathrm{C}$ for $30 \mathrm{~s}, 72^{\circ} \mathrm{C}$ for $40 \mathrm{~s}$ followed by $72^{\circ} \mathrm{C}$ for $7 \mathrm{~min}$ final extension and $20^{\circ} \mathrm{C}$ hold. In the nested PCR, a $2 \mu l$ portion of the primary PCR was amplified in a $25 \mu \mathrm{l}$ reaction prepared as above except for the use of primers MoV148F and MoV149R. Nested PCR cycling conditions were the same as for the primary PCR except for the use of a reduced annealing temperature $\left(58^{\circ} \mathrm{C}\right)$ and a shortened extension time $(30 \mathrm{~s})$. Aliquots $(8 \mu \mathrm{l})$ of the primary PCRs and nested PCRs were analysed in $2 \%$ agarose-TAE gels containing $0.5 \mu \mathrm{g} \mathrm{ml}^{-1}$ ethidium bromide. For sequence analysis, PCR or nested PCR products were purified using a QIAquick $^{\circledR}$ column and automated sequencing was performed in both directions using the forward and reverse PCR primers and the Big-Dye dye-terminator system (Applied Biosystems)

Digoxigenin-labelled DNA probe. The $776 \mathrm{bp} \mathrm{MoV}$ cDNA insert in pMoV4.1 (Cowley et al. 2005) was used to generate a random-primed, digoxigenin (DIG)labelled DNA probe. Briefly, pMoV4.1 DNA was digested with Pst I at sites in the UNI-primer flanking the insert (Cowley et al. 2000b, 2005) and the resulting $\sim 0.8 \mathrm{~kb}$ DNA was purified from a $1.2 \%$ LMP-agaroseTAE gel using a QIAquick $^{\circledR}$ column. DIG-labelled DNA was synthesised from $\sim 300 \mathrm{ng}$ pMoV4.1 insert DNA by overnight incubation at $20^{\circ} \mathrm{C}$, using the DIGHigh Prime system (Roche Molecular Biochemicals) containing DIG-11-dUTP, random primers and Klenow DNA polymerase as described in the kit instructions. DNA probe labelling efficiencies were quantified by dot-blotting 5 -fold dilutions of probe onto a Hybond $\mathrm{N}+$ membrane (Amersham Pharmacia Biotech) followed by detection using 1:2000 anti-DIG $\mathrm{F}_{\mathrm{ab}}$-alkaline phosphatase (Roche Molecular Biochemicals) and incubation in the dark with nitroblue tetrazolium (NBT) plus 5-bromo-4-chloro-3-indoyl phosphate (BCIP) substrate mixture according to the manufacturer's instructions.

Histology and in situ hybridisation. For histology, the cephalothorax of Penaeus monodon was separated from the abdomen, split longitudinally and 1 half was fixed in Davidson's fixative for 1 to $2 \mathrm{~d}$. Paraffin embedded tissues sections were processed for histology and were stained with haemotoxylin and eosin using standard methods (Bell \& Lightner 1988). For ISH detection of MoV RNA, tissue sections $(5 \mu \mathrm{m})$ mounted on Superfrost/Plus glass slides were reacted with $~ 30$ ng DIG-DNA probe per slide using the hybridisation, washing and the anti-DIG $\mathrm{F}_{\mathrm{ab}}$-alkaline phosphatase, NBT/BCIP detection protocols described in detail by Spann et al. (2003). Sections were counterstained using $0.5 \%$ Bismarck brown, dehydrated through a graded series of ethanol concentrations, cleared in xylene and mounted under cover slips. 
Transmission electron microscopy (TEM). Small $\left(<1 \mathrm{~mm}^{3}\right)$ diced pieces of prawn tissue were fixed in cacodylate buffer containing $2.5 \%$ glutaraldehyde and $2 \%$ paraformaldehyde for several days and post-fixed in $1 \%$ osmium tetroxide. Tissue pieces were dehydrated by sequential incubation in increasing concentrations of ethanol and were mounted in Spurr's resin (Spurr 1969). Cut tissue sections (50 nm) were mounted on $\mathrm{Cu}-200$ copper grids, stained with $0.5 \%$ uranyl acetate in $70 \%$ methanol and Reynold's lead citrate using a standard method and were examined under a Joel 1010 transmission electron microscope at $80 \mathrm{kV}$.

\section{RESULTS}

\section{Sensitivity limits of RT-nested PCR for MoV}

The sensitivity limits of PCR and nested PCR components of the MoV RT-nested PCR were assessed by endpoint analyses of 2 independent dilution series of RNA transcribed in vitro. Representative PCR and nested PCR analyses employing cDNA prepared to 1 of the RNA dilution series are shown in Fig. 1. A 610 bp RT-PCR product was detected with 20 RNA copies and a product was just detectable with 6 RNA copies. The same RT-PCR endpoint (6 RNA copies) was obtained when the CDNA series was retested. In the nested PCR, a 322 bp amplicon was clearly detected with 2 RNA copies (Fig. 1). cDNAs prepared in duplicate to an expanded RNA dilution series $(6,2,0.6$, 0.2 and 0.02 RNA copies) were amplified to validate the detection limits of the PCR and nested PCR (data not shown). PCR amplicons were just detectable at 6 RNA copies in 1 test and at 2 RNA copies in the other. The nested PCR did not extend the detection limit of either RT-PCR but amplicon yields, as in Fig. 1, were significantly higher and clearly visible.

\section{Tissue suitability for RT-nested PCR detection of $\mathrm{MoV}$}

The lymphoid organ is one of the primary tissues in which $\mathrm{MoV}$ can be detected by RT-PCR and ISH (Cowley et al. 2005). However, the collection of lymphoid organ is not suitable for nonsacrificial screening of valuable Penaeus monodon broodstock. The sensitivity of the MoV RTnested PCR was therefore assessed using gill, haemocytes and lymphoid organ tissue from individual $P$. monodon. Among 14 spent broodstock collected from a hatchery in September 2002, that originated from Innisfail in north Queensland, all were infected with $\mathrm{MoV}$ at levels detectable by RT-PCR and $610 \mathrm{bp}$ amplicon yields were similar for all tissues (Table 1). Among the group of 10 adult $P$. monodon originating from Weipa in the Gulf of Carpentaria, an amplicon was clearly detected by RT-PCR in 4 prawns using lymphoid organ RNA and barely detected in 5 prawns using either gill or haemocyte RNA (Table 2). The nested PCR detected MoV in only 1 additional gill sample and a MoV amplicon was detected in only 1 of the 10 prawns in all 3 tissue types. In an attempt to detect $\mathrm{MoV}$ more consistently in the different tissues, the RT-nested PCR was repeated using $5 \mu \mathrm{l}$ rather than $1 \mu \mathrm{l}$ cDNA (Table 2). In the repeated test, $\mathrm{MoV}$ was not detected in any additional lymphoid organ samples (4/10 positive) but was detected in 3 previously negative gill samples (9/10 positive) and in all 5 previously negative haemocyte samples (10 positive).

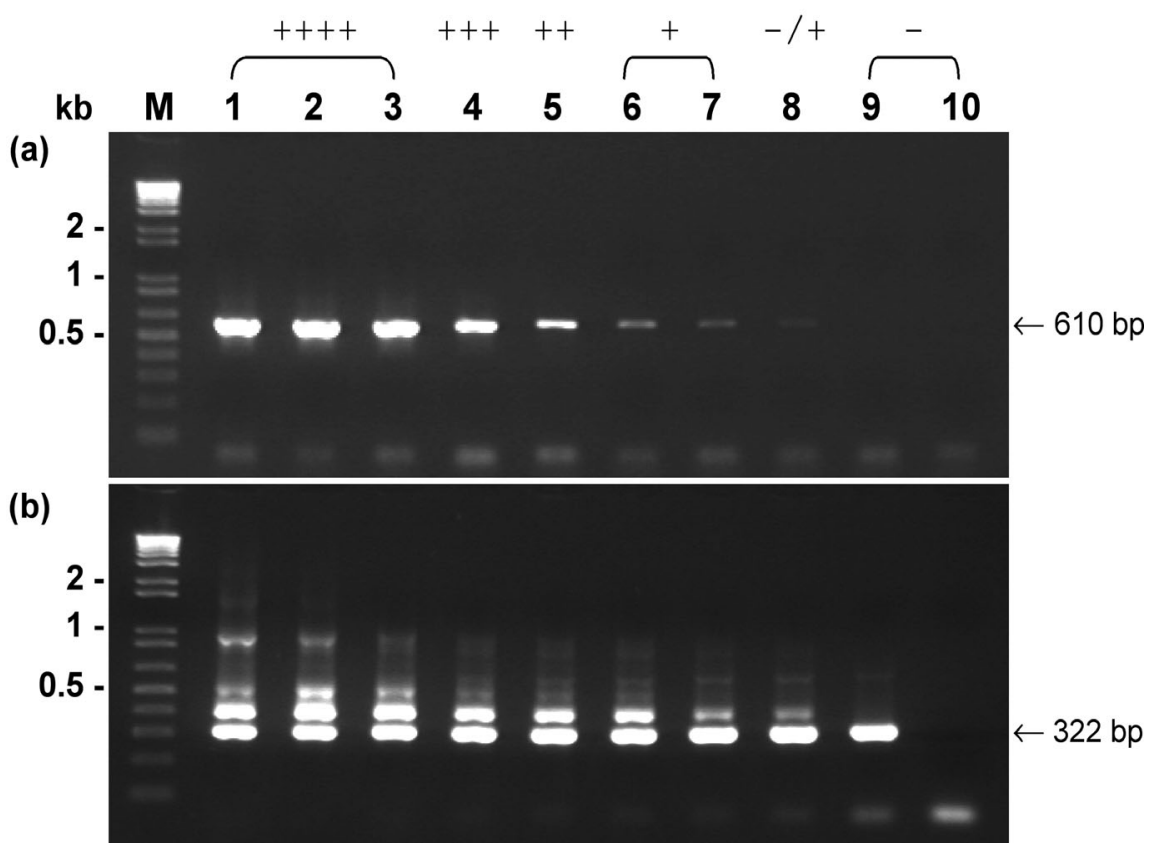

Fig. 1. Sensitivity limits of the MoV RT-PCR (primers MoV24F and MoV25R) and nested PCR (primers MoV148F and MoV149R) were determined by amplifying serial dilutions of MoV synthetic RNA from $2.0 \times 10^{6}$ RNA copies down to 0.2 RNA copies, ie Lane $1\left(2 \times 10^{6}\right)$, Lane $2\left(2 \times 10^{5}\right)$, Lane $3\left(2 \times 10^{4}\right)$, Lane $4\left(2 \times 10^{3}\right)$, Lane $5(200)$, Lane $6(60)$, Lane $7(20)$, Lane 8 (6), Lane $9(2)$, Lane $10(0.2)$. (a) The RT-PCR step amplifies a $610 \mathrm{bp}$ product (limit $=6$ RNA copies) and (b) the nested PCR amplifies a $322 \mathrm{bp}$ product (limit $=2$ RNA copies) internal to the RT-PCR product. PCR products were resolved in a $2 \%$ agarose-TAE gel containing $0.5 \mu \mathrm{g} \mathrm{ml}^{-1}$ ethidium bromide. $\mathrm{M}=1 \mathrm{~kb}$ PLUS DNA ladder (Invitrogen) 


\section{Prevalence of MoV detected by RT-PCR}

RT-PCR using lymphoid organ RNA was applied to assess the prevalence of MoV in Penaeus monodon broodstock randomly selected from commercial hatcheries and research facilities during 2002/2003. Among broodstock captured from the Innisfail to Cairns region of north Queensland, 14 prawns collected from a hatchery in September 2002 and 4 prawns collected from CSIRO Marine Research, Cleveland, in October 2002 were all RT-PCR positive for MoV. The RT-PCR also detected $\mathrm{MoV}$ in all of 17 broodstock supplied from the AIMS research facility, Cape Ferguson, in June 2002. These prawns were the third generation of captive-reared stocks derived from wild prawns from north-east Queensland. Among prawns collected from farms in south-east Queensland during the 2002-03 grow-out season, 15 of 16 prawns collected in Decem-

Table 1. RT-PCR detection of MoV in the lymphoid organ, gill and haemocytes of spent Penaeus monodon broodstock from a hatchery in September 2002 that originated from the Innisfail region of north Queensland. Amplified PCR product yields identified in agarose gels were scored $(-,-/+,+,++,+++$ or ++++$)$ based on the relative yields determined with the MoV synthetic RNA dilution series shown in Fig. 1. LO: lymphoid organ; Haem: haemocytes; +ve: positive control $P$. monodon $\mathrm{RNA}_{i}$-ve: negative control P. monodon RNA; NTC: no template water control; ND: not done

\begin{tabular}{|c|c|c|c|c|c|}
\hline $\begin{array}{l}\text { Prawn } \\
\text { no. }\end{array}$ & Sex & $\begin{array}{l}\text { Weight } \\
\text { (g) }\end{array}$ & LO & $\begin{array}{c}\text { RT-PCR } \\
\text { Gill }\end{array}$ & Haem \\
\hline 1 & F & 123 & ++++ & ++++ & ++++ \\
\hline 2 & $\mathrm{~F}$ & 137 & ++++ & ++++ & ++++ \\
\hline 3 & $\mathrm{~F}$ & 165 & + & ++ & ++ \\
\hline 4 & $\mathrm{~F}$ & 131 & ++++ & ++++ & ++++ \\
\hline 5 & M & 66 & ++++ & ++++ & ++++ \\
\hline 6 & M & 65 & ++++ & ++++ & ++++ \\
\hline 7 & M & 59 & ++++ & ++++ & +++ \\
\hline 8 & M & 59 & ++++ & ++++ & ++++ \\
\hline 9 & $\mathrm{~F}$ & 194 & ++++ & ++++ & +++ \\
\hline 10 & $\mathrm{~F}$ & 115 & ++++ & ++++ & ++++ \\
\hline 11 & $\mathrm{~F}$ & 122 & ++++ & ++++ & ++++ \\
\hline 12 & $\mathrm{~F}$ & 103 & ++++ & ++++ & ++++ \\
\hline 13 & $\mathrm{~F}$ & 142 & ++++ & ++++ & ND \\
\hline 14 & F & 109 & ++++ & ++++ & ++++ \\
\hline +ve control & & & ++++ & & \\
\hline -ve control & & & - & & \\
\hline NTC & & & - & & \\
\hline
\end{tabular}

ber 2002 and all of 10 prawns collected from another farm in May 2003 were RT-PCR positive for MoV. As MoV viral loads in most prawns were sufficient to be detected by RT-PCR, the nested PCR step of the test was not utilized.

\section{Sequence comparison of MoV isolates in individual prawns}

MoV RT-PCR amplicons generated from 5 spent hatchery broodstock originating from Innisfail in north Queensland in September 2002 were sequenced to assess the level of genetic diversity among isolates detected in individual prawns. In the 562 nucleotide (nt) region spanned by primers MoV24F and MoV25R, all 5 isolates possessed a single nucleotide variation $\left(\mathrm{GCT} / \mathrm{C}^{483}=\mathrm{Ala}\right)$ from the pMoV4.1 clone sequence at a locus toward the 5 '-end of the nested PCR primer MoV149R. Another variation $\left(\mathrm{AA} / \mathrm{G}^{146} \mathrm{~A}\right)$ occurred in one isolate that resulted in a structurally conservative (Lys $\rightarrow$ Arg) change in amino acid sequence. A MoV sequence obtained from diseased Penaeus monodon supplied from AIMS, Cape Ferguson, possessed a variation (G/A ${ }^{406} \mathrm{TC}$ ) at another position that also resulted in a structurally conservative (Val $\rightarrow$ Ile) amino acid change. Among nested PCR amplicons generated from 3 adult P. monodon collected from the Gulf of Carpentaria in March 2002, no sequence variations from cDNA clone pMoV4.1 were detected in the $274 \mathrm{nt}$ region spanned by primers pMoV148F and MoV149R. 


\section{MoV tissue tropism identified by ISH}

ISH using a DIG-labelled DNA probe to the $\sim 0.8 \mathrm{~kb}$ cDNA insert in pMoV4.1, was applied to examine the tissue distribution of $\mathrm{MoV}$ in Penaeus monodon with chronic, low-level infection and acute, high-level infection. Prawns examined included (1) healthy broodstock from hatcheries (2) healthy juvenile prawns from farm ponds in which there had been no evidence of disease (3) moribund prawns collected from farm pond edges during disease episodes and (4) diseased prawns generated experimentally by injection with a pathogenic inoculum (Spann et al. 1997, 2003). The pathogenic inoculum was derived from diseased, farmed P. monodon and RT-PCR and ISH testing showed that these prawns and the inoculum contained high levels of MoV in addition to GAV (data not shown).

MoV was not detected by RT-nested PCR in 4 healthy adult Penaeus monodon collected from the wild near Weipa in the Gulf of Carpentaria in March 2001. Routine histology on these prawns identified no lymphoid organ spheroids or pathology indicative of viral infection in any other cephalothoracic organ (data not shown). Consistent with these findings, no ISH signal was detected using the MoV probe. Sections from these prawns were used as negative controls in all ensuing ISH tests.

Healthy, female Penaeus monodon broodstock from CSIRO Marine Research, Cleveland, that had been caught near Innisfail in north Queensland in October 2002 were screened for MoV by RT-nested PCR and ISH. The prawns had not been ablated and spawned. Lymphoid organ RNA from each of 4 prawns examined was RT-PCR positive for MoV. In 2 of these prawns examined histologically, the only abnormality noted was the presence of extensive lymphoid organ spheroids (Fig. 2a), which at higher magnification displayed variable degrees of vacuolisation. In serial sections, MoV ISH signal of variable intensity occurred throughout hypertrophied cells of individual spheroids whilst generally less intense signal was evident in the cells of adjoining tubules (Fig. 2b). ISH signal also occurred in the cuticular epithelium lining the stomach (Fig. 2c) and cephalothoracic exoskeleton (Fig. 2d) of both prawns. Moreover, in 1 of the 2 prawns, MoV ISH signal was apparent in the periopod segmental nerve ganglion.

Among apparently healthy juvenile Penaeus monodon collected from a farm pond in April 2004, lymphoid organ RNA from each of 3 prawns sampled was RTPCR positive for MoV. In one prawn examined by histology, intense MoV ISH signal occurred in both lymphoid organ spheroids and normal tubules (data not shown). However, unlike the healthy broodstock examined, intense ISH signal was evident in the antennal gland (Fig. 2e) and in the connective tissue sur- rounding the tegmental glands (Fig. 2f) but none was evident in cuticular epithelial cells. In the 5 healthy P. monodon described above and in others examined to date with unapparent infections, MoV ISH signal has not been detected in any other cephalothoracic tissues, and the primary histopathology identified has been the existence, to variable severities, of lymphoid organ spheroids.

The ISH tissue distribution of MoV in Penaeus monodon displaying clinical signs of acute disease was initially assessed in moribund prawns generated by injection with a pathogenic inoculum. Mortality rates, gross signs of disease, histopathology and the tissue distribution of GAV, as determined by electron microscopy

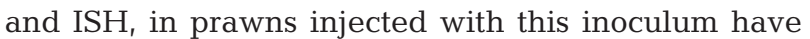
been reported previously (Spann et al. 1997, 2000, 2003). In 3 moribund prawns sampled $5 \mathrm{~d}$ after injection at a time when significant mortalities were occurring, MoV ISH signal was widespread throughout many cephalothoracic tissues (Fig. 3). Intense ISH signal indicative of high $\mathrm{MoV}$ viral loads occurred in both lymphoid organ spheroids and stromal matrix cells of normal non-occluded tubules. In many cases, intense ISH signal was more evident in cells around the lumen and the outer periphery of tubules (Fig. 3a). ISH signal also occurred in primary and secondary gill filaments, prominently in epithelial pillar cells (Fig. 3b), and in glial, neurosecretory and giant cells surrounding the periopod segmental nerve ganglia (Fig. 3c). In one prawn in which the supraesophageal ganglion was sectioned, ISH signal occurred in glial cells surrounding the anterior antennule neuropile (Fig 3d). However, no ISH signal occurred in nerve cell bodies in the ganglion. In the hepatopancreas, ISH signal occurred in the connective tissues between tubules and surrounding the organ, but not in hepatopancreocytes (Fig. 3e). ISH signal also occurred in the pericardial septum, epicardium and in fixed phagocytes within the myocardium (Fig. 3f), in haemocytes within haematopoietic tissues (Fig. 3g) and, as in healthy prawns (Fig. 2), in antennal gland tubules and in cuticular epithelium of the stomach and cephalothoracic exoskeleton.

In moribund Penaeus monodon collected from farm ponds experiencing mortalities, MoV ISH signal consistently occurred within both lymphoid organ spheroids and tubules and typically in cuticular epithelium, gills, nerve tissues, antennal gland and connective tissue of the hepatopancreas (data not shown). However, compared to moribund prawns with experimentally induced, acute MoV and GAV infections, more variability was observed in lymphoid organ spheroid prevalence and in MoV ISH detection and/or signal intensities in cephalothoracic tissues other than the lymphoid organ. 

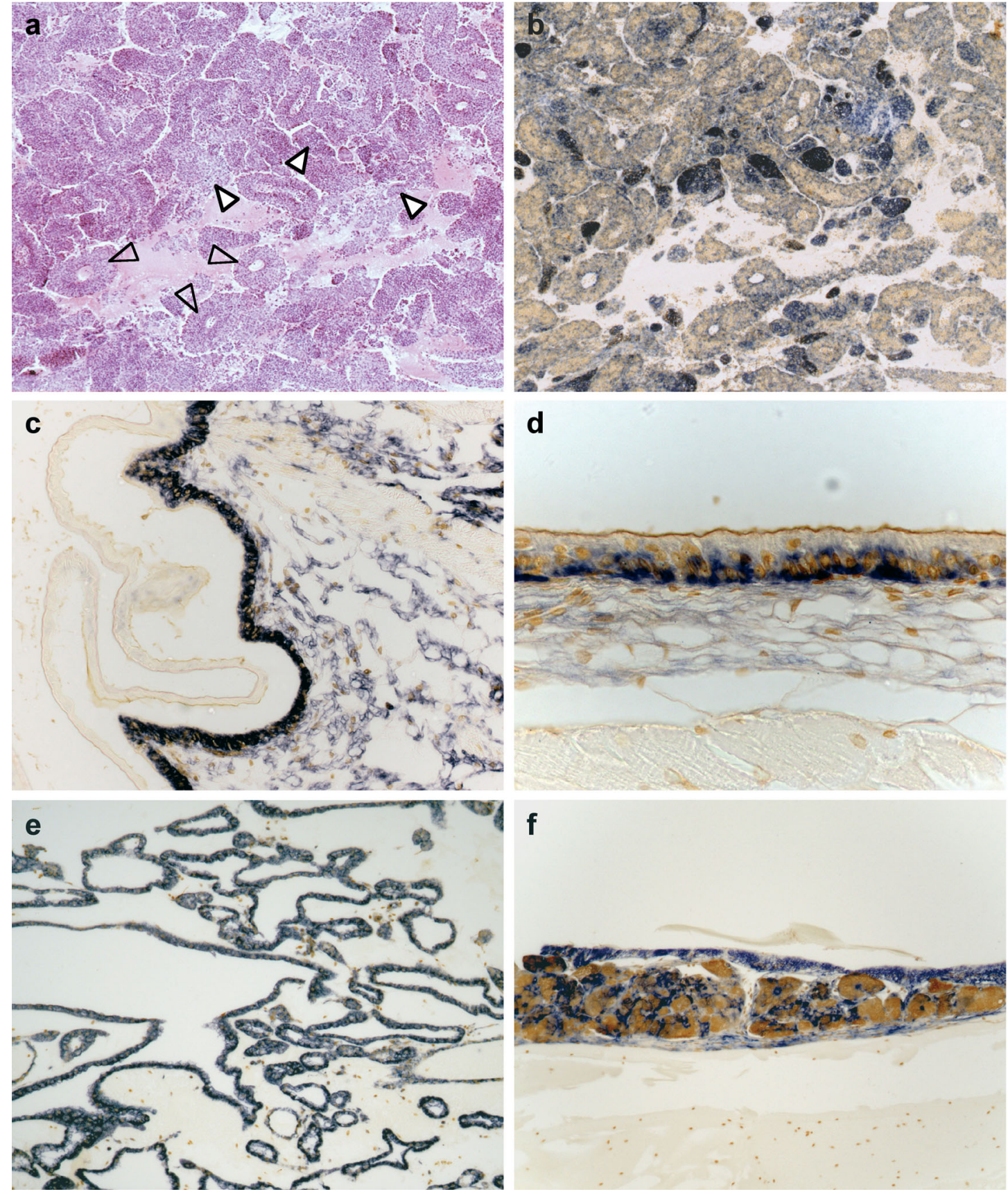

Fig. 2. Penaeus monodon. In situ hybridisation (ISH) detection of MoV in various tissues of healthy giant tiger prawns with an unapparent infection. (a) Section of the lymphoid organ showing spheroids (white arrowheads) and normal tubules (black arrowheads) (H\&E, 100×) and MoV ISH signal in (b) a serial section of the lymphoid organ (100×); (c) cuticular epithelium and underlying connective tissue lining the foregut $(100 \times)_{i}(\mathrm{~d})$ cuticular epithelium and underlying connective tissue of the cephalothoracic exoskeleton $(400 \times) ;(e)$ antennal gland tubules $(50 \times)$ and (f) tegmental glands $(100 \times)$

\section{MoV particle morphology and association with endoplasmic membranes}

TEM of tissue sections from moribund Penaeus monodon collected from eastern Australia between 1997 and 2000 identified spherical ( 85 $\mathrm{nm}$ diameter) to ovoid ( 85 $\mathrm{nm} \times 100 \mathrm{~nm})$, enveloped MoV particles as well as helical GAV nucleocapsids and rod-shaped, enveloped GAV virions. MoV particles were seen in regions adjacent to, and within the cytoplasm of a 

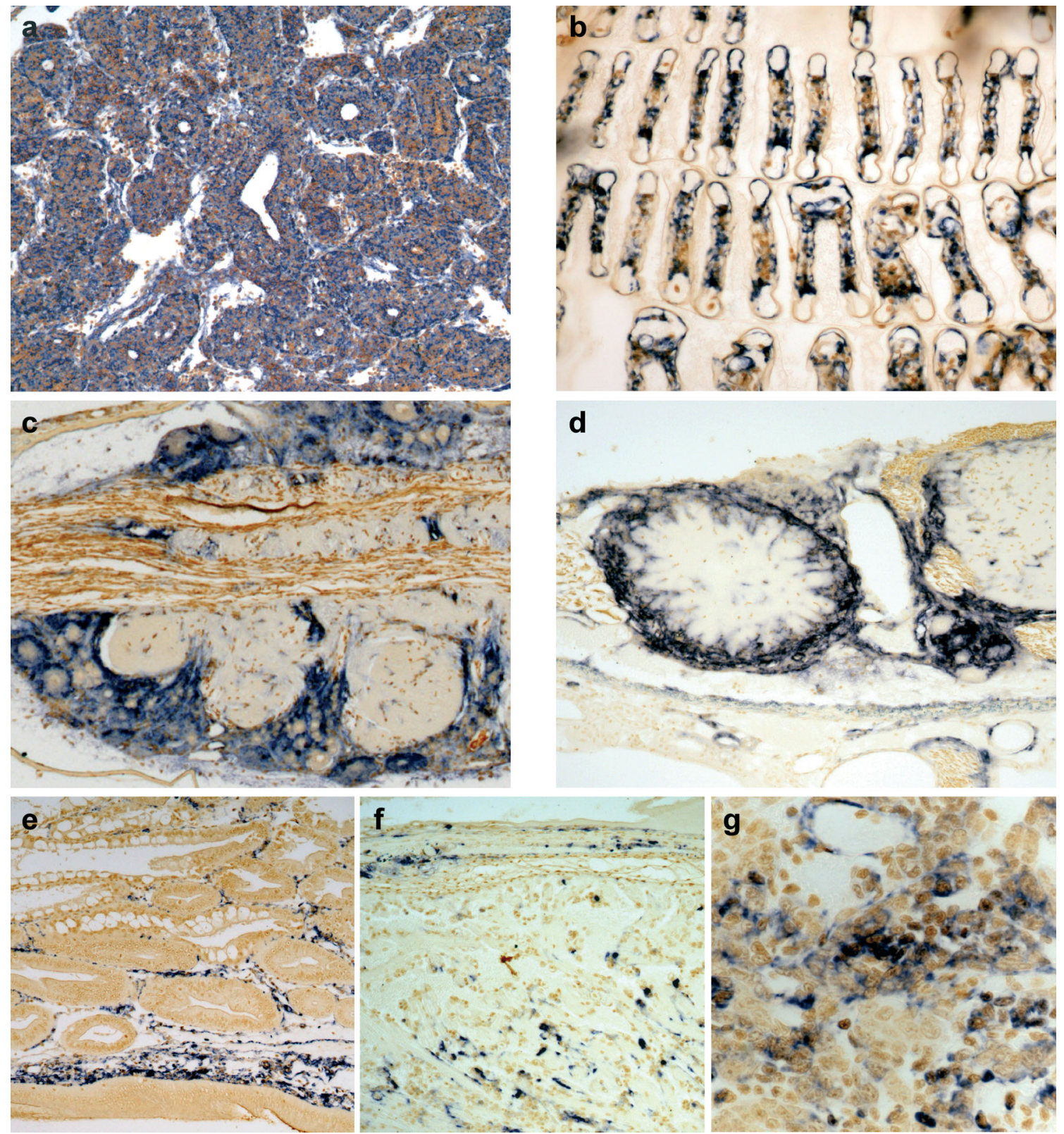

Fig. 3. Penaeus monodon. ISH detection of MoV in various tissues of moribund giant tiger prawns experimentally infected with an inoculum containing MoV and GAV, including (a) lymphoid organ (100×); (b) gills (200×); (c) segmental nerve ganglia (200×); (d) anterior antennule neuropile $(100 \times)_{i}(\mathrm{e})$ hepatopancreas and midgut $(100 \times)_{i}(\mathrm{f})$ heart $(1000 \times)_{i}$ and $(\mathrm{g})$ haematopoietic tissue $(400 \times)$

highly necrotic cell in the gill epithelium underlying the cuticle of a moribund P. monodon (Fig. 4). The prawn was sampled in 1997 and was from a cohort experiencing mortalities that had been reared in captivity for over 12 mo at the AIMS research facility in north Queensland. The cell type was difficult to ascertain accurately due to the advanced necrosis. An amorphous electron-dense structure likely to represent condensed chromatin was obvious and there were numerous unusual 'onion-ring' structures in the cell cytoplasm in which no normal organelles were discernible (Fig. 4a). At higher magnification, the rings of these structures appeared to comprise variably thickened, smooth endoplasmic membranes (Fig. 4b-d). $\mathrm{MoV}$ virions were often aligned along the outer membranous rim of the concentric ring structures (Fig. 4b) or associated with amorphous material that appeared to be derived from degenerated membranes (Fig. 4c,d). In regions bordering the cell membrane, MoV particles co-existed with GAV virions that, in some cases, 
adjoined the membrane and appeared to have budded from underlying nucleocapsids (Fig. 5a). MoV particles were also seen clustered within cytoplasmic vacuoles in some gill cells (Fig. 5b). The MoV virions were relatively uniform in size although particle-to-particle variations in electron density were apparent, as was the presence of a double-layer, electron-dense outer ring at the periphery of some particles (Fig. 5a,b). In the cytoplasm of another cell in the gill epithelium, a spherical MoV particle was seen in the vicinity of numerous unusual tubular structures that were similar in diameter ( 75-90 $\mathrm{nm})$ to the $\mathrm{MoV}$ particles and up to $\sim 570 \mathrm{~nm}$ in length (Fig. $5 \mathrm{c}$ ).

\section{DISCUSSION}

In this paper, we report on a sensitive RT-nested PCR test for Mourilyan virus (MoV), the use of ISH to assess the tissue distribution of MoV in healthy and diseased Penaeus monodon from eastern Australia and the morphology of MoV particles detected by TEM. Testing of
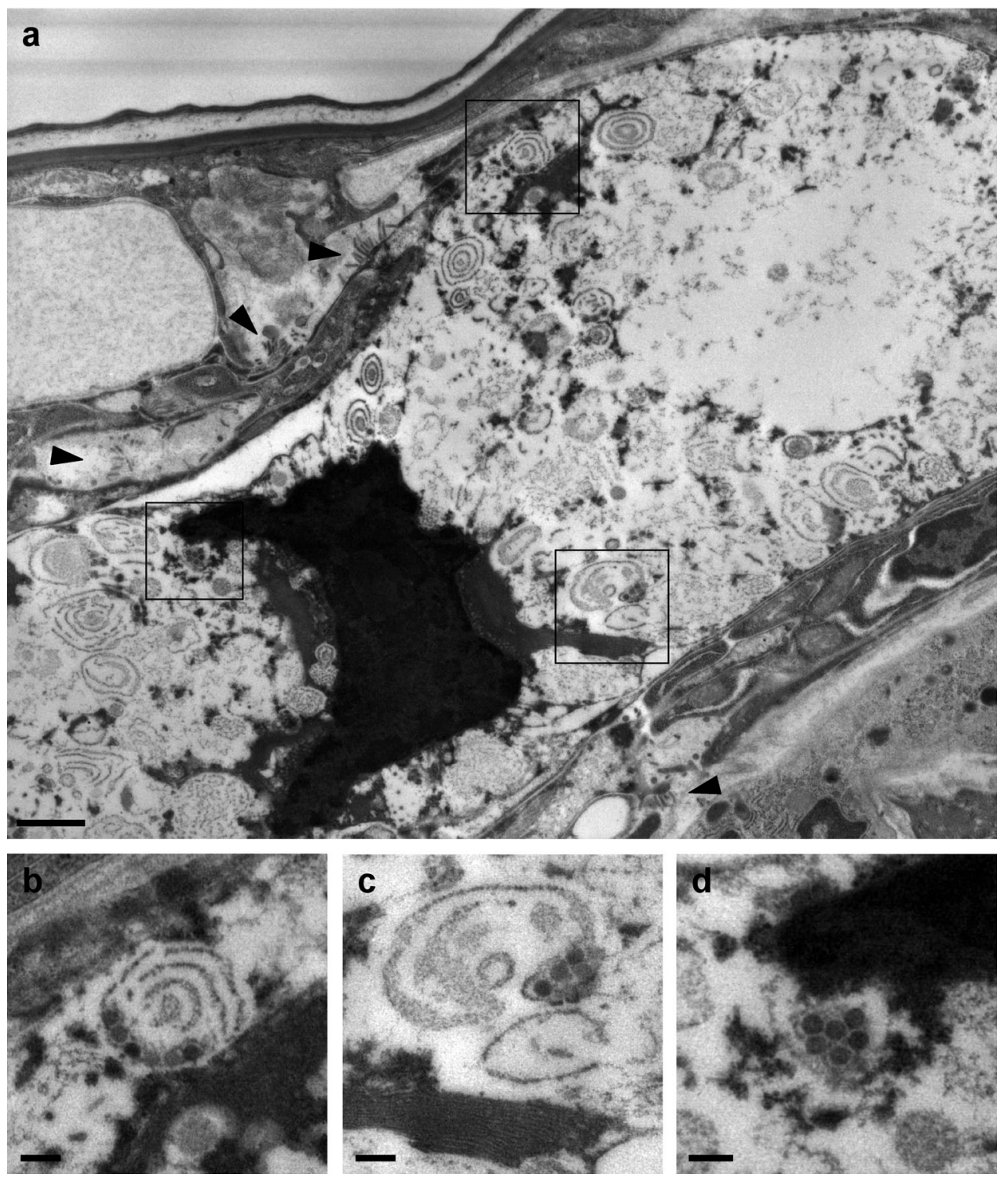

Fig. 4. Penaeus monodon. Transmission electron microscopy (TEM) of an ultra-thin section of gill tissue from a moribund adult prawn naturally infected with both MoV and GAV. (a) Low magnification of a highly necrotic cell showing numerous membranous 'onion ring' shaped structures. Mature 'rod-shaped' virions of GAV are evident in regions adjacent to the necrotic cell (arrowheads). Within the cell cytoplasm, boxed areas have been enlarged to show roughly spherical MoV virions (b) aligned along the outer rim of a ring structure, (c) clustered within amorphous material at the periphery of a ring structure and (d) clustered with amorphous material within a membranous structure. Scale bars = (a) $1 \mu \mathrm{m}$; (b) to (d) $200 \mathrm{~nm}$ 
dilution series of a MoV synthetic RNA showed the RTnested PCR to be extremely sensitive. The RT-PCR step reliably detected 20 RNA copies and in repeated tests, amplicons were just detected with 2 to 6 RNA copies. The nested PCR did not extend the detection limit beyond 2 to 6 RNA copies but amplicon yields were significantly greater and clearly detected in agarose gels. The RT-nested PCR sensitivity thus approaches the theoretical limit of 1 RNA copy and compares favourably to a similar test to detect GAV (Cowley et al. 2000a, de la Vega et al. 2004) and real- time RT-PCR tests for GAV (de la Vega et al. 2004) and other RNA viruses including YHV and TSV (Dhar et al. 2002). Moreover, as very few (less than $0.2 \%$ ) nucleotide changes occurred in MoV RT-PCR products amplified from $P$. monodon from eastern Australia, the test should be quite robust in detecting minor quasispecies variants present in this prawn population. The RT-nested PCR test has also been used successfully to detect a genotypic variant of $\mathrm{MoV}$ present in P. monodon originating from Malaysia (T. W. Flegel pers. comm.).
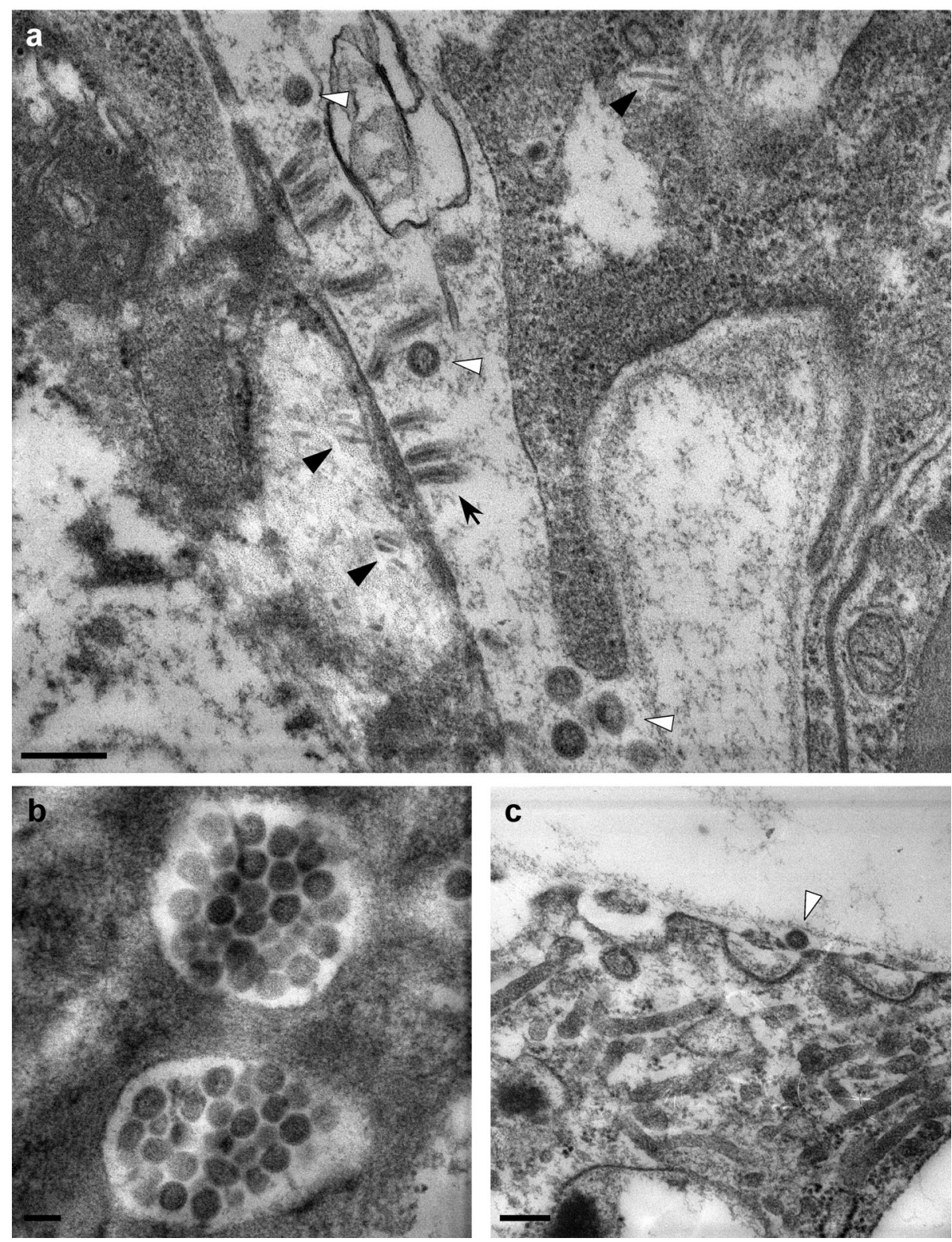

Fig. 5. Penaeus monodon. TEM showing (a) spherical to ovoid (approx. 85 to $100 \mathrm{~nm}$ diameter) MoV virions (white arrowheads) in proximity to GAV nucleocapsids (black arrowheads), some of which are aligned along a cellular membrane from which rodshaped GAV virions (arrow) are budding. (b) MoV virions within cytoplasmic vesicle-like structures and (c) a MoV virion (white arrowhead) in the vicinity of numerous cytoplasmic tubular structures ( 75 to $90 \mathrm{~nm}$ in diameter and up to $\sim 570 \mathrm{~nm}$ in length). Scale bars $=(\mathrm{a}),(\mathrm{c}) 200 \mathrm{~nm}$; (b) $100 \mathrm{~nm}$ 
RT-nested PCR data obtained from individual Penaeus monodon showed that the lymphoid organ, gill and haemocytes generate comparable amplicon yields when viral loads reach a level readily detectable by RT-PCR. However, in wild P. monodon captured from the Gulf of Carpentaria in which MoV was either barely detectable or undetectable by RT-nested PCR, positive reactions were obtained more often using RNA from either haemocytes or gill than from lymphoid organ (Table 2). Moreover, a 5-fold increase in the input cDNA improved the sensitivity of detection of $\mathrm{MoV}$ in gills and haemocytes. Thus, although higher RT-PCR amplicon yields can be obtained using lymphoid organ RNA, the use of haemocyte or gill RNA allows non-sacrificial sampling and detection of $\mathrm{MoV}$ in P. monodon with extremely low viral loads.

Among Penaeus monodon broodstock captured from the Innisfail to Cairns region of north Queensland and farmed and domesticated stocks generated from these broodstock sampled between September 2002 and May 2003, RT-PCR screening detected MoV in 60 of 61 (98\%) prawns tested. GAV is also endemic and occurs commonly in this population of $P$. monodon (Spann et al. 1995, Cowley et al. 2000a, Walker et al. 2001), which is the primary source of broodstock used to supply hatcheries in Queensland. It has been suggested that GAV may be maintained in this population by vertical transmission (Cowley et al. 2002). It will be important to determine whether MoV is also transmitted vertically and if so, the mechanisms by which this occurs.

Lymphoid organ spheroids, which are known to form in response to infection with several prawn viruses (Owens et al. 1991, Bonami et al. 1992, Spann et al. 1995, Hasson et al. 1999a,b), are thought to be a component of a mechanism to contain and possibly eliminate biotic and abiotic substances. There is evidence that spheroids represent partitioned packages of phagocytes and spent haemocytes (Hasson et al. 1999b, Anggraeni \& Owens 2000), but the processes by which they form or sequester viruses and/or infected cells are not well understood. MoV was detected by RT-nested PCR in gills and haemocytes of Penaeus monodon with low viral loads and, by ISH, MoV was consistently detected in both spheroids of normal tubules of prawns with moderate to high viral loads. In prawns acutely infected with MoV, virus particles were also identified by TEM in what appeared to be highly necrotic fixed phagocytes in the gill epithelia. Collectively these data suggest that haemocytes are a primary site of MoV infection. Moreover, MoV was characteristically detected by ISH in lymphoid organ tubules (often prominently in cells adjoining the tubule lumen and periphery) of both healthy and diseased prawns in which ISH-positive spheroids were also evident. As proposed for TSV (Hasson et al. 1999b), this suggests that normal tubule cells play a particularly active role in sequestering MoV from circulating haemolymph.

In healthy Penaeus monodon, MoV was less restricted to lymphoid organ spheroids than has been reported for GAV (Spann et al. 1995, 2003). ISH signal was prominent in hypertrophied cells of lymphoid organ spheroids that displayed variable degrees of vacuolisation. However, unlike GAV, MoV was also detected characteristically throughout the matrix of normal lymphoid organ tubules, often in the subcuticular epithelium underlying the stomach and exoskeleton and occasionally in nerve tissues and antennal and tegmental glands. In contrast, there were marked similarities in the tissue distribution of MoV with those reported for GAV in acutely infected $P$. monodon (Tang et al. 2002, Spann et al. 2003) and YHV (Tang \& Lightner 1999, Sithigorngul et al. 2002). In moribund prawns from farm disease outbreaks or from injection of an inoculum containing high levels of $\mathrm{MoV}$ and GAV, MoV was widely distributed throughout cephalothoracic tissues of mesodermal and ectodermal origin. Heavily infected tissues included lymphoid organ spheroids and tubules, gill and cuticular epithelium, particularly in the foregut and cephalothorax, organ connective tissues and glial, neurosecretory and giant cells in the segmental nerve ganglia (Fig. 3). However, in assessing this data, it is important to recognise that GAV was also present in the inoculum used for experimental infections (Spann et al. 1997) and occurs commonly in moribund $P$. monodon sourced from farms along eastern Australia (Spann et al. 1995, Cowley et al. 2000a, Walker et al. 2001). It will be important to conduct experimental infections in GAV-free prawns using an inoculum also free of GAV, to unequivocally demonstrate that $\mathrm{MoV}$ alone can induce disease and cause mortalities. Moreover, there is a need to determine the role of $\mathrm{MoV}$ in neuropathy and retinopathy that have been attributed to GAV (Callinan et al. 2003) and to cause morbidity and mortalities in P. monodon farmed in this region (Callinan \& Jiang 2003). To examine this, we are applying MoVspecific and GAV-specific ISH probes to serial sections of cephalothoracic tissues from $P$. monodon displaying these pathologies.

Bunyavirus particles are characteristically spherical to ovoid ( 95-105 $\mathrm{nm}$ diameter) in shape and possess a $\sim 5 \mathrm{~nm}$ thick lipid envelope covered in short $(\sim 9 \mathrm{~nm}$ long) diffuse surface projections (Murphy et al. 1968, 1973). Morphologically, the enveloped, spherical to ovoid particles of MoV ( 85-100 nm diameter) we detected by TEM are indistinguishable from bunyaviruses (Murphy et al. 1968, 1973) including Uukuniemi virus (UUKV) (Saikku \& Von Bonsdorff 1968, Von Bonsdorff et al. 1970, Von Bonsdorff \& Pettersson 1975), which is the most closely related genetically 
to $\mathrm{MoV}$ (Cowley et al. 2005). MoV particles were detected in the cytoplasm of, and nearby to, highly necrotic cells in the gill epithelium, which based on signals detected using ISH, might tentatively have been pillar cells. The particles were often associated with the outer rim of unusual concentric ring structures. Based on their prevalence and membranous morphology, these appear to be aberrant remnants of Golgi that had proliferated in response to $\mathrm{MoV}$, as commonly occurs in the latter stages of the replication cycle of bunyaviruses (Jantti et al. 1997, Salanueva et al. 2003). The nature of the cytoplasmic changes in these highly necrotic cells responsible for their aberrant morphology is not known. However, their association with virions and the presence of virions within cytoplasmic vacuoles suggests that, like other bunyaviruses, MoV matures at membranes of the Golgiendoplasmic reticulum (Jantti et al. 1997, Salanueva et al. 2003).

Elongated tubular viral structures can occur in cells infected with UUKV (Von Bonsdorff et al. 1970) and Bunyamwera virus (Salanueva et al. 2003). In Bunyamwera virus-infected cells, these occur particularly in the trans-Golgi and in proximity to mitochondria, and it has been hypothesised that the tubes might represent replication complexes or assembly intermediates integral to virion morphogenesis (Salanueva et al. 2003). Tubular structures (75-90 nm diameter and up to $\sim 570 \mathrm{~nm}$ long) similar in morphology to those seen in UUKV-infected cells were detected in gill cells nearby to MoV particles. However, additional TEM studies on the progress of infection are required to confirm their connection with MoV and to determine exactly how and where virions mature.

MoV particles closely resemble the enveloped spherical virions (50-96 nm diameter) found within cytoplasmic vesicles of cells within the fasciculate zone of the eye of diseased, farmed Penaeus monodon from eastern Australia (Smith 2000). MoV virions displayed less heterogeneity in size, and although most possessed an even electron density and a diffuse outer surface, a double outer membrane like that described by Smith (2000) was sometimes apparent. These similarities suggest that the virions reported by Smith (2000) were most likely MoV. It is possible the minor distinctions in size and morphology were due to differences in tissue fixation, sectioning and staining methods.

Among other crustacean viruses, MoV closely resembles the spherical enveloped particles (55-125 nm diameter) of crab haemocytopenic virus (CHV), also known as 'Roscoff' virus (Bang 1971, Hoover \& Bang 1976). CHV infects amebocytes of the European shore crab, Carcinus maenas, and interferes with haemolymph clotting (Bang 1971). Based on its size, morphology and intracellular budding at smooth endoplasmic membranes, CHV was tentatively reported to be a bunyavirus (Johnson 1983). More recently, another crab virus, Cancer pagurus systemic bunya-like virus ( $C p \mathrm{SBV})$, that forms bunyavirus-like enveloped, spherical to ovoid ( $70 \mathrm{~nm}$ diameter) particles with short tail-like structures has been shown to contain 3 ssRNA segments similar in length to those of bunyaviruses (Corbel et al. 2003). ISH using the probe described here, or probes to other regions in the $\mathrm{MoV}$ genome that are highly conserved among bunyaviruses, might prove useful in determining whether $\mathrm{MoV}$ is related genetically to these crab bunya-like viruses. Moreover, as MoV has been detected in haemocytes, work needs to be conducted to determine whether it impedes haemolymph clotting in Penaeus monodon as for CHV in crabs (Bang 1971),

As MoV infections also occur in Penaeus japonicus from eastern Australia, we are currently examining this and other prawn species that are not a natural host of GAV (Spann et al. 2000, Walker et al. 2001) to determine whether MoV can cause pathology and disease in the absence of GAV. In addition, progress has been made to delineate the MoV genome structure and complete sequence (Cowley et al. 2005), which provides unequivocal evidence that $\mathrm{MoV}$ is the first crustacean virus shown to be related genetically, as well as morphologically, to viruses of the Bunyaviridae. Complete genome sequences of $\mathrm{MoV}$ and of the recently reported $C p S B V$ of crabs (Corbel et al. 2003), that are the descendents of ancestral crustaceans existing over 500 million years ago (Siveter et al. 2001), should provide unique insights into the evolutionary origin of insect, vertebrate and plant bunyaviruses.

Acknowledgements. The authors wish to thank Gold Coast Marine Aquaculture, CSIRO Marine Research, Cleveland, and Matt Kenway at the Australian Institute of Marine Science (AIMS), Cape Ferguson, for supplying healthy and moribund Penaeus monodon. We also acknowledge financial support for parts of this research from the Fisheries Research \& Development Corporation of Australia.

\section{LITERATURE CITED}

Anggraeni MS, Owens L (2000) The haemocytic origin of lymphoid organ spheroid cells in the penaeid prawn Penaeus monodon. Dis Aquat Org 40:85-92

Bang FB (1971) Transmissible disease, probably viral in origin, affecting the amebocytes of the European shore crab, Carcinus maenas. Infect Immun 3:617-623

Belcher CR, Young PR (1998) Colourmetric PCR based detection of monodon baculovirus (MBV) in whole Penaeus monodon postlarvae. J Virol Methods 74:21-20

Bell TA, Lightner DV (1988) A handbook of normal shrimp histology. World Aquaculture Society, Baton Rouge, LA

Bonami JR, Lightner DV, Redman RM, Poulos BT (1992) Par- 
tial characterization of a togavirus (LOVV) associated with histopathological changes of the lymphoid organ of penaeid shrimps. Dis Aquat Org 14:145-152

Callinan RB, Jiang L (2003) Fatal, virus-associated peripheral neuropathy and retinopathy in farmed Penaeus monodon in eastern Australia. II. Outbreak descriptions. Dis Aquat Org 53:195-202

Callinan RB, Jiang L, Smith PT, Soowannayan C (2003) Fatal, virus-associated peripheral neuropathy and retinopathy in farmed Penaeus monodon in eastern Australia. I. Pathology. Dis Aquat Org 53:181-193

Corbel V, Coste F, Bonami JR (2003) CpSBV, a systemic virus of the edible crab, Cancer pagurus (L.). J Fish Dis 26: 121-126

Cowley JA, Dimmock CM, Wongteerasupaya C, Boonsaeng V, Panyim S, Walker PJ (1999) Yellow head virus from Thailand and gill-associated virus from Australia are closely related but distinct viruses. Dis Aquat Org 36: 153-157

Cowley JA Dimmock CM, Spann KM, Walker PJ (2000a) Detection of Australian gill-associated virus (GAV) and lymphoid organ virus (LOV) of Penaeus monodon by RTnested PCR. Dis Aquat Org 39:159-167

Cowley JA, Dimmock CM, Spann KM, Walker PJ (2000b) Gill-associated virus of Penaeus monodon prawns: an invertebrate virus with ORF1a and ORF1b genes related to arteri- and coronaviruses. J Gen Virol 81:1473-1484

Cowley JA, Hall MR, Cadogan LC, Spann KM, Walker PJ (2002) Vertical transmission of gill-associated virus (GAV) in the black tiger prawn Penaeus monodon. Dis Aquat Org 50:95-104

Cowley JA, McCulloch RJ, Spann KM, Cadogan LC, Walker PJ (2005) Preliminary molecular and biological characterisation of Mourilyan virus (MoV): a new bunya-related virus of penaeid prawns. In: Walker PJ, Lester RG, Bondad-Reantaso MG (eds) Diseases in Asian Aquaculture V. Proceedings of the 5th Symposium on Diseases in Asian Aquaculture, Gold Coast, Australia. Asian Fisheries Society, Manila (in press)

de la Vega E, Degnan BM, Hall MR, Cowley JA, Wilson KJ (2004) Quantitative real-time RT-PCR demonstrates that handling stress can lead to rapid increases of gillassociated virus (GAV) infection levels in Penaeus monodon. Dis Aquat Org 59:195-203

Dhar AK, Roux MM, Klimpel KR (2002) Quantitative assay for measuring the Taura syndrome virus and yellow head virus load in shrimp by real-time RT-PCR using SYBR Green chemistry. J Virol Methods 104:69-82

Doubrovsky A, Paynter JL, Sambhi SK, Atherton JG, Lester RJG (1988) Observations on the ultrastructure of baculovirus in Australian Penaeus monodon and Penaeus merguiensis. Aust J Freshw Res 39:743-749

Fraser CA and Owens L (1996) Spawner-isolated mortality virus from Australian Penaeus monodon. Dis Aquat Org 27:141-148

Hasson KW, Lightner DV, Mohney LL, Redman RM, Poulos BT, White BM (1999a) Taura syndrome virus (TSV) lesion development and the disease cycle in Pacific white shrimp Penaeus vannamei. Dis Aquat Org 36:81-93

Hasson KW, Lightner DV, Mohney LL, Redman RM, White BM (1999b) Role of lymphoid organ spheroids in chronic Taura syndrome virus (TSV) infections in Penaeus vannamei. Dis Aquat Org 38:93-105

Hoover KL, Bang FB (1976) Histopathological effects of a virus infection in the shore crab, Carcinus maenas. Proceedings of the 1st International Colloqium on Invertebrate Pathology, Kingston, Ontario, p 310-311
Jantti J, Hilden P, Ronka H, Makiranta V, Keranen S, Kuismanen E (1997) Immunocytochemical analysis of Uukuniemi virus budding compartments: role of the intermediate compartment and the Golgi stack in virus maturation. J Virol 71:1162-1172

Johnson PT (1983) Diseases caused by viruses, Rickettsiae, bacteria, and fungi. In: Smith DE (ed) The biology of Crustacea, Vol 6. Academic Press, New York, p 2-78

Krabsetsve K, Cullen BR, Owens L (2004) Rediscovery of the Australian strain of infectious hypodermal and haematopoietic necrosis virus (IHHNV). Dis Aquat Org 61:153-158

Murphy FA, Harrison AK, Tzianabos T (1968) Electron microscopic observations of mouse brain infected with Bunyamwera group arboviruses. J Virol 2:1315-1325

Murphy FA, Harrison AK, Whitfield SG (1973) Bunyaviridae: Morphologic and morphogenetic similarities of Bunyawera serogroup viruses and several other arthropod-borne viruses. Intervirology 1:297-316

Nash M, Nash G, Anderson IG, Shariff M (1988) A reo-like virus observed in the tiger prawn, Penaeus monodon Fabricus, from Malaysia. J Fish Dis 11:531-535

Owens L (1993) Description of the first haemocytic rod-shaped virus from a penaeid prawn. Dis Aquat Org 16:217-221

Owens L, de Beer S, Smith JR (1991) Lymphoidal parvo-like virus from Australian penaeid prawns. Dis Aquat Org 11: 129-134

Owens L, Anderson IG, Kenway M, Trott L, Benzie JAH (1992) Infectious hypodermal and haematopoietic necrosis virus (IHHNV) in an interspecies hybrid penaeid prawn of tropical Australia. Dis Aquat Org 14:219-278

Owens L, Haqshenas G, McElnea C, Coelen R (1998) Putative spawner-isolated mortality virus associated with mid-crop mortality syndrome in farmed Penaeus monodon from northern Australia. Dis Aquat Org 34:177-185

Owens L, McElnea C, Snape N, Harris L, Smith M (2003) Prevalence and effect of spawner-isolated mortality virus on the hatchery phases of Penaeus monodon and P. merguiensis in Australia. Dis Aquat Org 53:101-106

Saikku P, Von Bonsdorff CH (1968) Electron microscopy of the Uukuniemi virus, an ungrouped arbovirus. Virology 34:804-806

Salanueva IJ, Novoa RR, Cabezas P, Lopez-Iglesias C, Carrascosa JL, Elliott RM, Risco C (2003) Polymorphism and structural maturation of bunyamwera virus in Golgi and post-Golgi compartments. J Virol 77:1368-1381

Sithigorngul $\mathrm{P}$, Rukpratanporn S, Longyant S, Chaivisuthangkura P, Sithigorngul W, Menasveta P (2002) Monoclonal antibodies specific to yellow-head virus (YHV) of Penaeus monodon. Dis Aquat Org 49:71-76

Siveter DJ, Williams M, Waloszek D (2001) A phosphatocopid crustacean with appendages from the Lower Cambrian. Science 293:479-481

Smith P (2000) Diseases of the eye of farmed shrimp Penaeus monodon. Dis Aquat Org 43:159-173

Spann KM, Vickers JE, Lester RJG (1995) Lymphoid organ virus of Penaeus monodon from Australia. Dis Aquat Org 23:127-134

Spann KM, Cowley JA, Walker PJ, Lester RJG (1997) A yellow-head-like virus from Penaeus monodon cultured in Australia. Dis Aquat Org 31:169-179

Spann KM, East IJ, Donaldson RA, Cowley JA, Walker PJ (2000) Differences in the susceptibility of some penaeid prawn species to gill-associated virus (GAV) infection. Dis Aquat Org 42:221-225

Spann KM, McCulloch RJ, Cowley JA, East IJ, Walker PJ (2003) Detection of gill-associated virus (GAV) by in situ hybridization during acute and chronic infections of $P e-$ 
naeus monodon and $P$. esculentus. Dis Aquat Org 56:1-10 Spurr AR (1969) A low-viscosity epoxy resin medium for electron microscopy. J Ultrastructure Res 26:31-43

Tang KFJ, Lightner DV (1999) A yellow head virus probe: nucleotide sequence and application for in situ hybridization. Dis Aquat Org 35:165-173

Tang KFJ, Spann KM, Owens L, Lightner DV (2002) In situ detection of Australian gill-associated virus with a yellow head virus gene probe. Aquaculture 205:1-5

Vickers JE, Webb R, Young PR (2000) Monodon baculovirus from Australia: ultrastructural observations. Dis Aquat Org 39:169-176

Editorial responsibility: Timothy Flegel,

Bangkok, Thailand
Von Bonsdorff CH, Pettersson R (1975) Surface structure of Uukuniemi virus. J Virol 16:1296-1307

Von Bonsdorff CH, Saikku P, Oker-Blom N (1970) Electron microscope study on the development of Uukuniemi virus. Acta Virol 14:109-114

Walker PJ, Cowley JA, Spann KM, Hodgson RAJ, Hall MR, Withyachumnarnkul B (2001) Yellow head complex viruses: transmission cycles a topographical distribution in the Asia-Pacific region. In: Browdy CL, Jory DE (eds) The New Wave: Proceedings of the Special Session on Sustainable Shrimp Culture, Aquaculture 2001. The World Aquaculture Society, Baton Rouge, LA, p 227-237

Submitted: October 21, 2004; Accepted: March 26, 2005

Proofs received from author(s): August 12, 2005 